\title{
Private household demand for vehicles on alternative fuels and drive trains: a review
}

\author{
Laurence Turcksin • Olivier Mairesse $\cdot$ Cathy Macharis
}

Received: 16 November 2012 / Accepted: 6 February 2013 / Published online: 27 February 2013

(C) The Author(s) 2013. This article is published with open access at SpringerLink.com

\begin{abstract}
Purpose Any attempt of the government to encourage the purchase of vehicles on alternative fuels and drive trains will depend on the acceptance of the end-users on the demand side. This paper offers an in-depth understanding of the consumers' attitudes and preferences towards AFVs which can guide the government to establish effective policy measures.

Method A comprehensive review of research is performed under different conceptual frameworks and research methodologies: attitudinal, experimental, preference valuation studies and others. Research findings are reported with the general objective to (1) uncover the attitudes and preferences towards AFVs and (2) examine whether the environmental benefits of AFVs play a role in the car purchase decision.

Results Overall, there exists a strong environmental concern, and positive attitudes towards AFVs. However, environmental benefits are of little importance in the car purchase decision, which is principally driven by price characteristics, performance and convenience attributes. Limited knowledge levels also seem to prevent building up awareness of AFVs, which is the key to their adoption. Conclusions The adoption of AFVs is likely to be limited without significant governmental incentives and regulations. Based on the key findings, it can be recommended that a combination of educational campaigns (e.g., information tools), pricing measures (e.g., differentiated vehicle taxation), supply-sided measures and large-scale demonstrations is required to support the adoption of AFVs.
\end{abstract}

L. Turcksin $\cdot$ O. Mairesse $\cdot$ C. Macharis $(\bowtie)$

Research Group MOBI, Vrije Universiteit Brussel, Pleinlaan 2,

1050 Brussels, Belgium

e-mail: Cathy.Macharis@vub.ac.be

C. Macharis

Logistics and Transport Research Group,

Vrije Universiteit Brussel, Brussels, Belgium
Keywords Consumer preferences · Alternative fuels and drive trains $\cdot$ Private households $\cdot$ Review $\cdot$ Environment

\section{Introduction}

Two important factors have caused major evolutions and developments in the transportation and automotive sector and have stimulated the use of new technologies for our transportation models: the availability of energy sources and the important adverse effects of transportation systems on the environment [93]. The finite nature of oil resources and the associated political and economic effects presently lead to the need of assessing alternative energy sources and to reduce the dependence on imported oil. In addition to these energy aspects, the transportation sector is responsible for a substantial part of pollutant emissions in the atmosphere, which are directly and indirectly impacting different receptors such as people, material, agriculture, climate and ecosystems [92]. To reduce the harmful emissions and to make the use of finite energy sources more efficient, effective policy measures need to be installed by the relevant authorities. One effective approach to attain these objectives is to reduce the use of personal transportation by encouraging the use of the bicycle and public transport [73]. However, most consumers are not inclined to let go their primary means of transportation, mainly because of strong feelings of convenience and independence associated with car use [7]. Therefore, encouraging the purchase of alternatives to conventional petrol and diesel vehicles is essential. Vehicles on alternative fuels such as liquefied petroleum gas (LPG), compressed natural gas (CNG), biofuels and hydrogen and drive trains such as electric vehicles (EVs), (plug-in) hybrid electric vehicles ((P)HEVs) and hydrogen fuel cell vehicles (HFCVs) offer an attractive solution to reduce the environmental impact of the vehicle fleet [48].

A large scale adoption of these AFVs is a great challenge. It depends not only on large-scale infrastructure costs, such as refuelling and recharging facilities on the supply-side, but 
also on the acceptance by the end-users on the demand side. It is now widely recognised that each attempt to change the consumers' activities and lifestyles requires a sound knowledge of preferences and determinants of consumer demand [75]. In this respect, unveiling the consumers' attitudes and preferences towards AFVs is necessary for the formulation of effective policy measures.

Literature on the potential demand for AFVs has mainly emerged since the late $80 \mathrm{~s}$ and has been studied under very different conceptual frameworks. This paper conducts a comprehensive literature review and presents a classification scheme to map and uncover (1) the preferences and attitudes towards AFVs and (2) whether their environmental benefits can become a new dimension of vehicle choice by consumers. Section 2 outlines the search strategy, whereas Section 3 presents the main findings of the literature review according to the applied conceptual framework and research methodology. Section 4 concludes and provides policy recommendations.

\section{Search strategy}

According to Cooper [28], a research review should be designed in a systematic, objective way. To this extent, the integrative research review consists of several stages. The first stage is the formulation of the research question(s), which will guide the research. Here, the aim is to uncover consumer preferences for AFVs and to examine whether the environmental benefits of AFVs play a role in the car purchase decision. The second stage is the determination of the data collection strategy and a selection of multiple channels in order to avoid a bias in coverage (Section 2.1). The third stage, elaborated in Section 2.2, provides an evaluation and selection of the retrieved data. The fourth stage contains an analysis and interpretation of the reviewed literature (Section 2.3) which finally leads to the presentation of the results (Section 3) [19].

\subsection{Data collection strategy}

The data collection strategy is based on a computerised search. Articles were mainly retrieved by tracking cited references from e-catalogues. The reviewed papers were published mainly since the last two decades. Several sources were used to search for literature. These included the web-based search tools (V-spaces, article database; "web of science" and other e-sources) and the VUBIS e-catalogue from the library of the Vrije Universiteit Brussel (VUB). In addition, web-search robots (e.g., Google Scholar) were used to track cited references and to find publication titles, using the search term 'alternative fuels and drive trains' combined with 'purchase behaviour', 'private household demand', 'environment' and 'consumer preferences'. From the resulting output, the relevant hits were filtered out based on their publication in peer-reviewed journals, citation index (Min.
1, except for recently published articles, see Table 1) and their focus on the purchase of AFVs by private households.

\subsection{Evaluation of the retrieved data}

By using the above described strategy, 53 publications have been retained for further analysis. First, the retrieved data show divergences according to the applied conceptual framework and research methodology (see Table 2). They can be grouped into attitudinal, experimental, preference valuation and other studies. The majority of the collected articles applied preference valuation techniques (27), followed by attitudinal surveys (14), experimental designs (8) and others (4). Many articles involve a combination of them. Especially attitudinal surveys are often used in a first phase to develop the survey instrument or to obtain in-depth information about the consumers' attitudes on environmental issues. Second, research from the 80 s and 90 s mainly focused on the potential demand for battery EVs $[13,14,24,27,38,39,54,55,79,90]$, while studies from the late 90s and 2000s rather address a mix of AFVs including EVs, LPG, CNG or methanol [21-23,33,34,42,81,87]. In line with technological developments, recent research also concentrates on HEVs $[3,10,26,29,31,32,45,49,53,72]$, PHEVs $[9,11]$, biofuels $[51,68,69,80,89,91]$, hydrogen $[2,66,74,76,86]$ and HFCVs $[46,61,62,65]$. Finally, most literature has been published in America. Out of the 53 reviewed articles, 19 were carried out in California, 10 in other US states and 7 in Canada. Europe is represented with 16 articles and Asia with 1 article. The bias towards California as the geographical focus of attention could be attributed to the heightened awareness of air pollution due to local conditions and press attention [37,87], its importance in global HEV sales (25\% of total US sales in 2006) [45], the low-emission vehicle regulations and state programs $[39,87]$ and the highest count of Green Party registered voters throughout the US [53]. Only recently, European studies have gained in number, especially in the field of attitudinal surveys and preference valuation techniques.

\subsection{Analysis and interpretation of literature}

Based on the evaluation of the retrieved data, the research findings will be treated according to the applied conceptual framework and research methodology (see next Section 3).

\section{Results}

In the following subsections, the conceptual frameworks and research methodologies are briefly described and an overview of common cited critics is given. Then, the major findings are listed and general themes and response patterns are observed. 
Table 1 Citation indices of the retrieved peer-reviewed articles

${ }^{\mathrm{a}}$ Recently published

\subsection{Attitudinal studies}

Attitude theory [30] is a central concept in environmental psychology and typically relates attitudes to behaviour

\begin{tabular}{|c|c|c|c|}
\hline Study & Citation index & Study & Citation index \\
\hline Achterberg et al. [2] & 1 & Johansson-Stenman and Martinsson [52] & 70 \\
\hline Ahn et al. [3] & 12 & Kahn [53] & 51 \\
\hline Axsen et al. [10] & 12 & Kurani et al. [54] & 47 \\
\hline Axsen and Kurani [9] & 5 & Kurani et al. [55] & 45 \\
\hline Axsen et al. [11] & 10 & Lundquist Noblet et al. [60] & 7 \\
\hline Beggs and Cardell [13] & 36 & Martin et al. [61] & 2 \\
\hline Beggs et al. [14] & 309 & Mau et al. [62] & 12 \\
\hline Brownstone et al. [21] & 37 & Mourato et al. [65] & 29 \\
\hline Brownstone et al. [22] & 223 & O’Garra et al. [66] & 36 \\
\hline Bunch et al. [23] & 93 & Peters et al. $[67]^{\mathrm{a}}$ & - \\
\hline Calfee [24] & 32 & Petrolia et al. [68] & 4 \\
\hline 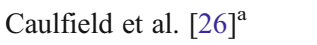 & - & Popp et al.[69] & 3 \\
\hline Chéron and Zins [27] & 8 & Potoglou and Kanaroglou [72] & 33 \\
\hline Dagsvik et al. [29] & 26 & Ricci et al. [74] & 3 \\
\hline Eggers and Eggers $[31]^{\mathrm{a}}$ & - & Segal [79] & 20 \\
\hline Erdem et al. [32] & 1 & Schulte et al. [76] & 45 \\
\hline Ewing and Sarigöllü [33] & 32 & Solomon and Johnson [80] & 19 \\
\hline Ewing and Sarigöllü [34] & 48 & Sperling et al. [81] & 10 \\
\hline Flamm [35] & 7 & Thesen and Langhelle [86] & 1 \\
\hline Gjoen and Hard [36] & 28 & Tedeshi et al. [85] & 6 \\
\hline Gould and Golob [39] & 21 & Tompkins et al. [87] & 14 \\
\hline Golob and Gould [38] & 9 & Turrentine and Kurani [88] & 63 \\
\hline Greene [42] & 25 & Ulmer et al. [89] & 8 \\
\hline Heffner et al. [45] & 27 & Urban et al. [90] & 208 \\
\hline Heffner et al. [46] & 2 & Van de Velde et al. [91] & 1 \\
\hline Horne et al. [49] & 26 & Van Rijnsoever et al. [94] & 2 \\
\hline Jensen et al. [51] & 1 & & \\
\hline
\end{tabular}

Table 2 Evaluation of the retrieved data

The number between brackets represents the amount of reviewed studies out of a total of 53 publications through an intermediary intention construct. One of the most applied theories to study behaviours of environmental relevance is the theory of planned behaviour (TPB) [5]. This theory stipulates that behavioural intention is shaped by 
attitudes towards the specific behaviour (overall evaluation of its possible consequences), subjective norms (the perception of a person about the normative expectations of others such as close friends or family) and perceived behavioural control (PBC) (personal feeling that one could easily change its behaviour and that one has the possibilities to do this). TPB pretends that if attitudes and subjective norms are favourable, the PBC will be larger and the intention for behavioural change will be stronger [4,5]. In this context, the adoption of an AFV will be immediately influenced by a person's intention to adopt the technology. Other conceptual frameworks in the field of environmental psychology include the normactivation model (NAM) (by [77,78]), which focuses on moral values and personal norms to explain (altruistic) behaviour, and the value-belief-norm (VBN) theory (by $[83,84]$ ) to explain commitments to protect the environment.

Methodological approaches to measure the correlation between attitudes and behaviour in environmental psychology often apply quantitative methods, qualitative methods (e.g., semi-structured interviews, focus groups, group discussions etc.) or a combination of both.

Although the TPB and other theories are well tested, they rely on complicated links between consumer values, knowledge, beliefs, attitudes, intentions and behaviour. A large size of factors is often difficult to quantify, predict and manage and even if they are known, there is a loose causal link between intentions and actions. The explanatory value of attitudes on behaviour is thus limited, but might enlarge when behaviour measures are self-reported, than when observed $[8,75]$. In addition, the choice of survey questions might be subjected to potential biases (e.g., framing, sample selection bias etc.). Quantitative surveys might for example provide less opportunity to let people frame their own public perceptions and attitudes than qualitative surveys, but the latter encounters the limitation of being representative for wider populations [74].

Table 3 shows an increasing emergence of attitudinal surveys within the last 7 years, mainly executed in Europe. Except for Ricci et al. [74] and Schulte et al. [76], quantitative surveys were applied to reveal the consumer preferences for AFVs. Within the surveys, there is a predominance of measuring the attitudes towards hydrogen $[2,66,74,86]$ and biofuel vehicles $[69,89,91]$. Overall, the general concern about environmental issues is found to be high (general positive environmental attitudes), but very often, this is not translated into changes in purchasing behaviour $[2,66,74,94]$. This discrepancy between environmental attitudes and ecological behaviour is known as the attitude-action gap [56]. Most of the reviewed studies have addressed this attitude-action gap and have consistently reported two findings.

First, attitudes and behaviour towards AFVs are not merely determined by environmental considerations, but are the outcome of a complex trade-off involving economic $[69,74,89]$, performance $[66,74,86]$ and psychological factors [67] including less conscious determinants such as status [52] and symbolic motives [67]. Moreover, individuals will rather value the environmental benefits of AFVs in terms of potential monetary savings, than out of environmental concern $[69,89]$.

Second, limited knowledge levels currently prevent to build up awareness of AFVs, which is the key to their adoption $[66,74,86]$. Prior levels of AFV knowledge and hence awareness are found to be associated with sociodemographic (e.g., gender, age) and personal characteristics (e.g., education) $[66,86]$, environmental knowledge $[35,66,86,94]$, pro-environmental attitudes [35,86], cultural dispositions [2], product involvement [66,94], direct experience (e.g., in terms of practical experiences and demonstrations) and familiarity with AFVs [74,94].

Besides attitudes, an increased belief of the ability to influence the environment positively ( $\mathrm{PBC}$ ) is found to affect behavioural change in the same way $[67,69,91]$. To strengthen the $\mathrm{PBC}$, information is required that focuses on the opportunities and possible solutions (e.g., range of actions that can be taken within car purchase to reduce energy problems), instead of messages that contain negative information and strengthen the seriousness of the problem and its detrimental consequences $[66,69,91]$.

The need for information is a recurrent finding throughout most of the reviewed studies [2,35,66,74,85,91]. Audiences are found to behave differently and require information to be differentiated according to the interests and knowledge levels, socio-demographic characteristics, attitudes and cultural dispositions of the specific target audience $[2,74,91,94]$. Performance attitudes are found to be positively related to information search [94], whereas people with environmental attitudes are less affected by information provision $[91,94]$. In this respect, tailored information which focuses on the new technical developments that improve environmental performance while maintaining car performance might for example help to enhance the support for AFVs [94].

\subsection{Experimental studies}

In experimental and quasi-experimental studies, individuals are put in a natural or an artificial setting to observe their behaviour towards a group of individuals not exposed to the experimental treatment. Experimental studies often make use of vehicle trials or clinics, activity-based approaches, gaming simulations or design spaces $[11,55]$. Activity analysis includes the use of household travel diaries, activity location maps, videos and other informational material to observe daily travel patterns and understand consumers' needs with respect to AFVs [55]. Gaming simulations are experimental contexts in which respondents seek solutions to a particular problem or issue (e.g., range limit) within their activity space $[40,55]$. Design spaces are used to elicit the consumers' design priorities and preferences of AFVs, 


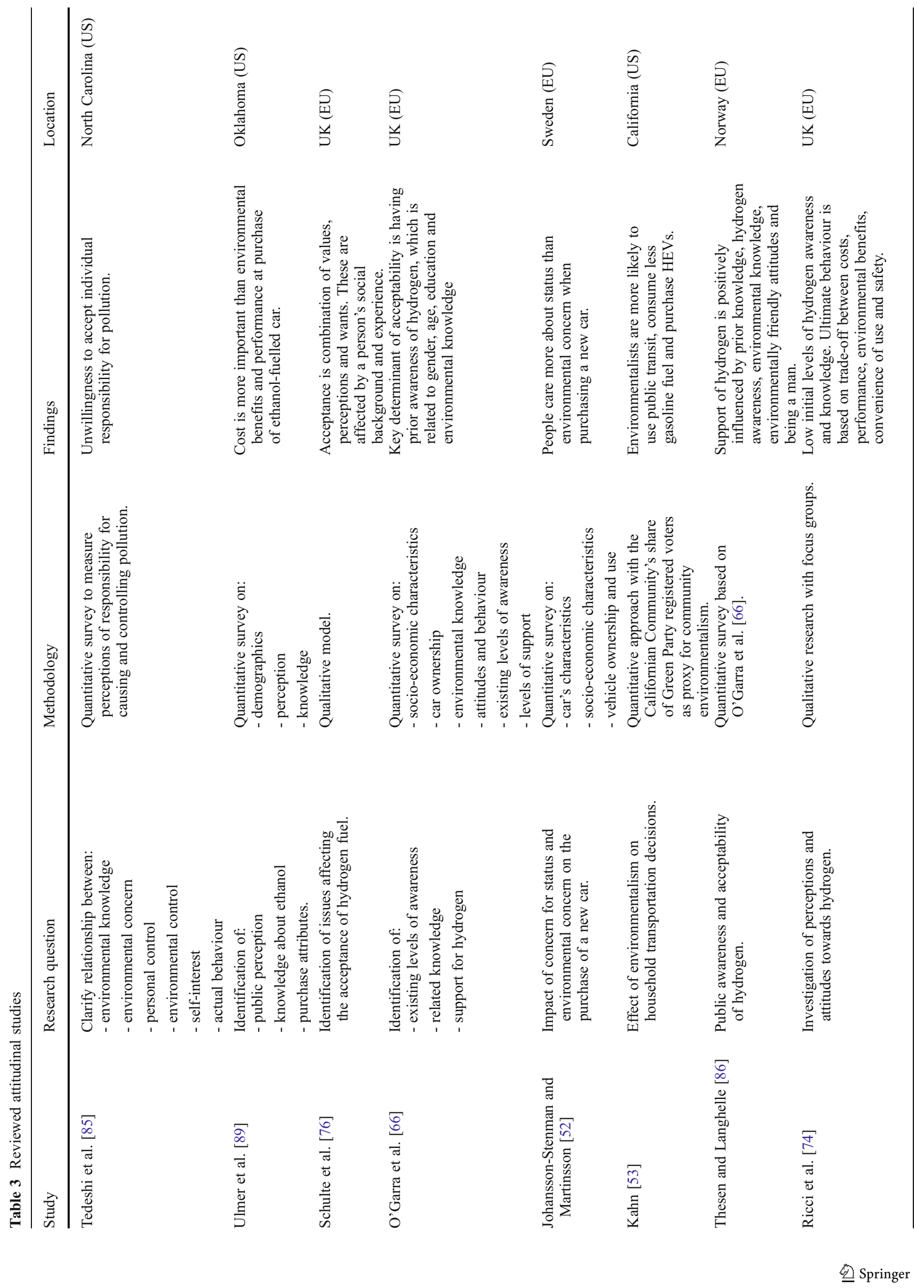




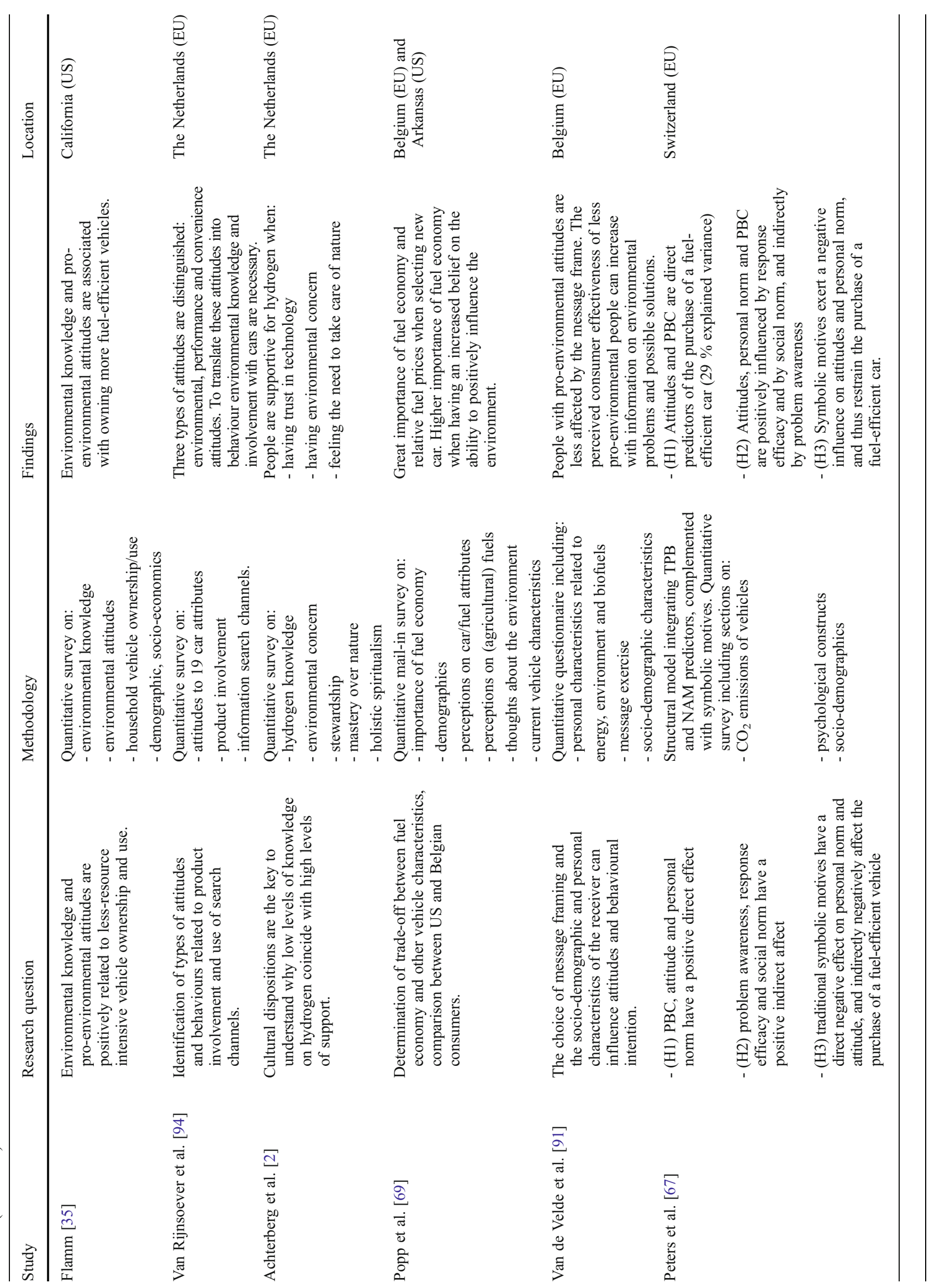


which is consistent with theories of constructed preferences that view consumer preferences as outcomes (and not as inputs) of decision contexts and processes [11,15].

Although experimental designs rely on virtual or realworld experiences of the technology and are more realistic than other survey techniques, they have their limitations. Trials may for example evoke the "Hawthorne" effect, indicating that people will produce upward biased estimates of interest in AFVs since they receive special attention. As a result, fewer people than those who expressed a purchase intention are likely to purchase such a car. Additionally, there may arise several measurement problems related to the duration and length of the trial. Trials may also provide reactions to a specific category or product because of the opportunity that the participants have to experience competing technologies (e.g., conventional gasoline cars) [39].

All reviewed experimental studies, displayed in Table 4, were performed in California (US). Many of them were carried out in the 90s to understand how consumers could address EV limitations. In line with technological developments, recent experimental studies rather concentrate on HFCVs and PHEVs. All vehicle technologies included in the experimental designs face driving range and infrastructure challenges and rely on an electric motor powered by a unique fuel source $[55,61]$.

Most experimental studies shared the opinion that there is a strong concern for the environment, and a strong belief that lifestyle changes are required to solve environmental problems $[38,39,54,55,90]$. However, they also discovered that the environment was the lowest rate issue when purchasing a vehicle (see for example [55,90]). Although environmental awareness may not lead to the purchase of an $\mathrm{AFV}$, it might encourage households to seek out and evaluate AFVs for purchase considerations [55].

Short-term exposure improves the respondents' overall impressions of AFVs, especially with respect to their environmental benefits $[39,61]$. But, as they gain experience with $\mathrm{AFVs}$, those perceived environmental benefits become a lower priority as other vehicle features will enter the decision set [39]. On the one hand, comparisons will be made based on range, purchase price and convenience of use [38]. Some of the

Table 4 Reviewed experimental studies

\begin{tabular}{|c|c|c|c|c|}
\hline Study & Scope & Experimental setting & Findings & Location \\
\hline Urban et al. [90] & EV & $\begin{array}{l}\text { Multi-media workshop placing } \\
\text { consumers in a virtual buying } \\
\text { environment. }\end{array}$ & $\begin{array}{l}\text { Although EVs were rated highly in terms } \\
\text { of environmental attributes, environmental } \\
\text { concern was the lowest rated issue when } \\
\text { purchasing a vehicle. }\end{array}$ & California (US) \\
\hline Kurani et al. [54] & EV & $\begin{array}{l}\text { Interactive interview based on } \\
\text { week-long travel diaries }\end{array}$ & $\begin{array}{l}\text { Perceived driving range is smaller than } \\
\text { expected. Viable market for EVs with } \\
60 \text { to } 100 \text { miles driving range. }\end{array}$ & California (US) \\
\hline Kurani et al. [55] & EV & $\begin{array}{l}\text { Experiment-oriented interviews } \\
\text { Innovative mail survey with: } \\
\text { - video of EV use and recharging } \\
\text { - 3-day trip diary } \\
\text { - map of activity locations } \\
\text { Vehicle choice experiments. }\end{array}$ & $\begin{array}{l}\text { Although environmental awareness may } \\
\text { not lead to the purchase of an EV, it may } \\
\text { encourage households to seek out and } \\
\text { evaluate EVs for purchase considerations. } \\
\text { Home recharging is the most highly valued } \\
\text { attribute, whereas environmentalism is the } \\
\text { least valued. }\end{array}$ & California (US) \\
\hline Gould and Golob [39] & $\mathrm{EV}$ & $\begin{array}{l}\text { Personal vehicle trials with: } \\
\text { - inboard travel logger } \\
\text { - a fill-in travel diary } \\
\text { - pre- and post-trial survey }\end{array}$ & $\begin{array}{l}\text { Although opinions about environmental } \\
\text { efficacy showed improvement after the trial, } \\
\text { participants would choose an EV on the basis } \\
\text { of other factors (e.g., low running costs) than } \\
\text { the environmental benefit. }\end{array}$ & California (US) \\
\hline Golob and Gould [38] & EV & $\begin{array}{l}\text { Personal vehicle trials with: } \\
\text { - inboard travel logger } \\
\text { - a fill-in travel diary } \\
\text { - pre- and post-trial survey }\end{array}$ & $\begin{array}{l}\text { Experience with EV did not change the } \\
\text { perception of the desired range (i.e., similar } \\
\text { to that of a gasoline car). }\end{array}$ & California (US) \\
\hline Martin et al. [61] & $\mathrm{HFCV}$ & $\begin{array}{l}\text { Real-driving and refuelling } \\
\text { experience, pre- and post- } \\
\text { clinic surveys. }\end{array}$ & $\begin{array}{l}\text { Short-term exposure improved the respondent's } \\
\text { overall impression of HFCV. A driving range } \\
\text { of } 480 \mathrm{~km} \text { is found to be acceptable for } 90 \% \\
\text { of the respondents. }\end{array}$ & California (US) \\
\hline Axsen and Kurani [9] & PHEV & $\begin{array}{l}\text { Attitudinal survey, travel } \\
\text { and parking diaries, } \\
\text { design games. }\end{array}$ & $\begin{array}{l}\text { More new vehicle buyers might be adapted for } \\
\text { vehicle recharging than generally assumed. } \\
\text { Home recharging is the key determinant for } \\
\text { an early PHEV market. }\end{array}$ & California (US) \\
\hline Axsen et al. [11] & PHEV & $\begin{array}{l}\text { Attitudinal survey, travel } \\
\text { and parking diaries and } \\
\text { design games. }\end{array}$ & $\begin{array}{l}\text { The performance requirements of batteries } \\
\text { might be closer to commercially viable } \\
\text { PHEVs than expected. }\end{array}$ & California (US) \\
\hline
\end{tabular}


reviewed studies reveal that respondents did not change their perception about the desired range $[38,39,61]$. Despite the demonstrated utility of AFVs, respondents still desire ranges to be similar to that of a conventionally fuelled car, even when travel diaries showed that they were usually travelling less on a daily basis $[38,61]$. Acceptable driving ranges are found to be $160 \mathrm{~km}$ for EVs [38,54] up to $480 \mathrm{~km}$ for HFCVs [61]. On the other hand, consumer preferences might emerge with respect to the new qualities of AFVs (e.g., quiet ride, low maintenance costs) $[38,54,55]$. In this respect, Kurani et al. [55] argue that multi-vehicle households will combine AFVs and conventional vehicles in their stock to achieve the advantages of the different propulsion systems. These "hybrid households" will not be discouraged by the limited driving range of AFVs as they allocate household travel according to the different operational characteristics of the vehicles (i.e., conventional vehicles for longer trips, AFVs for shorter trips). The attractiveness of AFVs will not lie in their competitive, but in their complementary relation to conventionally fuelled vehicles. In addition, Kurani and his colleagues assert that any disutility of reduced range can be more than offset by the value of home recharging $[9,11,55]$. They stipulate that a succesful market launch of AFVs will not depend on the duplication of the performance attributes of conventionally fuelled vehicles, but on the recognition that there is a potential market for less ambitious AFV designs with shorter driving ranges. According to these authors, the commercialisation of more ambitious AFVs should be inevitably accompanied with financial incentives, large-scale vehicle demonstrations and persuasive information campaigns to overcome the financial barriers and the lack of inherent interest.

\subsection{Preference valuation studies}

Preference valuation studies are another technique to analyse the potential demand for environmental goods or services which are usually not traded within the market mechanism. Consumer preferences are usually inferred by stated or revealed preference techniques. The stated preference (SP) technique is a survey-based technique that allows researchers to uncover how people value different product/service attributes. The most common SP techniques used in transport studies are the choice modeling (CM) method and the contingent valuation method (CV). CM originates from conjoint analysis, information integration theory in psychology [6] and discrete choice theory in economics/econometrics [58,59]. It applies a choice experiment approach using a variety of instruments (e.g., pencil and paper, computer aided personal survey instrument (CAPI), internet-based survey) to indirectly elicit attribute values based on either ranking or rating of products described by a number of attributes in several labelled or unlabelled choice sets $[18,41,47]$. Subsequently, via statistical techniques, the analysis will derive a value for each of these attributes and thus express the relative preferences among vehicle attributes $[29,79]$. Conventional discrete choice (DC) models analyse situations in which respondents are asked to choose one alternative from a set of mutually exclusive hypothetical alternatives $[17,50]$. Recently, multiple discretecontinuous extreme value (MDCEV) models have been introduced that deal with the existence of multiple-vehicle households, where households own and use multiple vehicles for satisfying their travel needs $[16,17]$. Other recent progresses in CM aim to improve realism, by for instance adding a nochoice option [31], or by customising attribute levels based on respondent's current vehicle choices $[10,31,62]$.

In $\mathrm{CV}$, value elicitation is whole-product based by asking respondents to express their maximum willingness to pay (WTP) for a given improvement of a public good provision level (e.g., cleaning up a lake) or for public goods aspects of a market good (e.g., eco-labeled goods) [44,63]. In the dichotomous CV design (yes/no answers), respondents accept or refuse a payment for a change in the quality or the quantity of a good at a given cost, while open-ended questions (such as payment cards and bidding games) provide a way to elicit the respondent's maximum WTP $[63,64]$. CV and CM offer rather different merits and their use entirely depends on the purpose of the study under consideration. CM is particularly suited to measure the marginal value of changes in various characteristics of environmental goods and allows a deeper understanding of the trade-offs between attributes, whereas $\mathrm{CV}$ is a better technique than $\mathrm{CM}$ when the main objective of the study is to value an overall policy package and for assisting in policy evaluations $[25,43,44,50]$.

Economists have been sceptical towards the use of SP data. One possible problem with hypothetical choices is that it may not reflect the real purchase intentions of the respondents (i.e., hypothetical bias) $[20,47]$. Another criticism is that SP surveys view consumer preferences as inputs to decision contexts and processes and assume that consumers have preferences for attributes that are unfamiliar to them. Consequently, these surveys might not capture the complexity of vehicle purchase behaviour $[9,15,39,55]$. Moreover, respondents tend to give socially desirable responses, such as "feel good" responses for environmental benefits or they may provide in contrast anti-environmental survey responses [55]. As a result, they may signal their preference for provision of less pollution, although in reality they would not spend any extra money on purchasing an environmentally friendlier car. Ewing and Sarigöllü [34] also point out that people who are highly concerned about the environment may have a higher motivation to return the surveys. Finally, Kurani et al. [55] state that surveys usually question one person from a household, while vehicle purchases are often made jointly by the whole household. In the literature on $\mathrm{CV}$, an extensive overview of potential sources of bias is given by Mitchell and Carson [63], Carson [25], 
Bateman et al. [12] and Venkatachalam [95], which can also offer guidance on how to cope with potential bias in hypothetical choice experiments [47].

In contrast to the SP technique, the revealed preference (RP) technique uses real market data from observations on actual choices in order to measure the consumer preferences. So RP data or market data do not have the possibility for confusion or unstated assumptions. But the main problem in predicting a market for AFVs by using RP data is the absence of actual choice observations since only a small market share of AFVs is currently available [70,71]. Furthermore, using RP data makes it difficult to observe the effect of large variations in the variables of interest. Finally, RP data may often produce strong correlations between the variables (multicollinearity) and may evoke difficulties in measuring the vehicle attributes [1]. Because SP and RP have complementary strengths, a growing body of literature applies joint SP-RP modeling techniques (e.g., [10,22]).

Except for Brownstone et al. [22] and Axsen et al. [10], all studies, listed in Table 5, applied SP surveys with a predominance of $\mathrm{CM}$, used for the identification of unique attributes of AFVs and their effects on vehicle purchase. All reviewed studies from the 80s and 90s were performed in America and focused on battery EVs or on a mix of AFVs including either EVs, LPG, CNG or methanol. Later research also included HEVs, PHEVs and HFCVs in the vehicle choice experiments. These reviewed CM studies reveal that the most critical factors for the adoption of AFVs are price characteristics (e.g., purchase price, fuel costs) [3,26,29,33,72,79], followed by performance and convenience attributes (e.g., driving range, recharging times, fuel availability) $[13,14,21,24,27,29,33,42,72,79]$. Although people express a willingness to pay for reduced emission levels [21,23,87], environmental benefits are consistently found to be of minor importance compared to these attributes $[26,27,34,72]$.

Recent studies also apply CM to capture the dynamics in consumer preferences for new technologies $[10,31,62]$. These studies reveal that conventional vehicles become less desirable with increases in $\mathrm{AFV}$ adoption, given equal monetary costs (i.e., neighbour effect) $[10,31,62]$. However, these dynamics in consumer preferences seem to depend on the type of new technology. Consumers will more likely switch to HEVs than to HFCVs [62] or to EVs [31]. This can be attributed to the fact that HEVs exhibit low switching costs (e.g., no reliance on the availability of charging stations), whereas HFCVs and EVs possess attributes that are unfamiliar to consumers (e.g., driving range) and require technical infrastructure (e.g., to recharge the car at home) $[31,62]$.

A minority of the reviewed SP studies applied the CV method. In recent years, this method was especially applied to unveil the WTP for biofuels $[68,80,81]$, HFCVs [65] and HEVs [32]. Similar to other CV literature, the WTP for AFVs is found to be positively influenced by income
$[32,80]$ and environmental concern $[32,51,65,80,81]$. Despite these levels of environmental concern and supportive attitudes towards AFVs, the WTP is mainly determined by financial considerations. The high initial costs of HEVs currently prevent them from gaining a market share (e.g., in Turkey) [32], the WTP for HFCVs is driven mostly by expectations of personal financial savings (e.g., reduced running costs) [65] and there only exists a WTP for methanol if the cost burden is shared [81].

To widen the acceptance of AFVs, these studies suggest that policymakers should act on the environmental concerns by issuing educational campaigns to raise awareness about the features and benefits of AFVs $[31,32,65]$. In this respect, consumers seem to react more to emission information (ecolabelling) at the vehicle level than at the class level [60]. In addition, tax incentives (e.g., surcharge of dirtier fuels, differentiation of vehicle taxes based on fuel economy or $\mathrm{CO}_{2}$ emissions), subsidies or private privileges (e.g., free parking) should make these vehicles more financially competitive as compared to conventionally fuelled vehicles [32,65]. Finally, the availability of a refuelling or recharging network could be ensured by the deployment of public charging stations, which is likely to be facilitated by the involvement and cooperation between all major stakeholders [31].

\subsection{Other studies}

A fundamentally different approach is symbolism, which does not focus on monetary costs and functional attributes to predict the adoption of AFVs, but on the symbolic meanings associated with them. Studies of symbolism either rely on conceptual frameworks from psychology (see [57,82]) or on ethnographic interviews which originate from anthropology (i.e., semiotics) (see [45,46]). The former studies used socialscientific research techniques to illustrate that the attractiveness of car use not only depends on instrumental-reasoned factors (e.g., travel costs, safety), but also on symbolicaffective motivations (e.g., status and social comparison, feelings of self-expression, feelings of sensation). The latter studies by Heffner et al. $[45,46]$ assume that vehicles are important carriers of symbolic meanings that are used to maintain (product as self-expression) and create (product as self-creation) self-identity. By selecting a particular vehicle, people communicate their interests, beliefs, values and social status.

Semiotic theory often uses qualitative surveys as they allow participants to use their own terminology and value frameworks. In addition, it might overcome some of the challenges associated with the examination of symbolic meanings, such as the tendency to understate the impact of symbolic meanings in vehicle purchases $[45,46]$. On the other hand, this approach relies on the existence of AFVs on the market and associated symbolic meanings, which take time to appear and to communicate [75]. 
Table 5 Reviewed preference valuation studies

\begin{tabular}{|c|c|c|c|c|c|}
\hline Study & Scope & Attributes & Method & Findings & Location \\
\hline $\begin{array}{l}\text { Beggs and } \\
\text { Cardell [13] }\end{array}$ & $\mathrm{EV}$ & $\begin{array}{l}\text { Price, operating cost, range, } \\
\text { recharging time, performance, } \\
\text { size and air conditioning. }\end{array}$ & $\mathrm{CM}$ & $\begin{array}{l}\text { Small market share of EVs as a result } \\
\text { of high negative valuation of limited } \\
\text { range and long recharging times. }\end{array}$ & Baltimore (US) \\
\hline Beggs et al. [14] & $\mathrm{EV}$ & $\begin{array}{l}\text { Price, operating cost, range, } \\
\text { recharging time, performance, } \\
\text { size and air conditioning. }\end{array}$ & $\mathrm{CM}$ & $\begin{array}{l}\text { Small market share of EVs as a result } \\
\text { of range anxiety and long recharging } \\
\text { times. }\end{array}$ & Baltimore (US) \\
\hline Calfee [24] & $\mathrm{EV}$ & $\begin{array}{l}\text { Price, operating cost, range, } \\
\text { top speed, number of seats }\end{array}$ & $\mathrm{CM}$ & $\begin{array}{l}\text { Great heterogeneity in consumer } \\
\text { trade-offs among vehicle attributes, } \\
\text { with range and top speed being } \\
\text { generally highly valued. }\end{array}$ & US \\
\hline $\begin{array}{l}\text { Bunch } \\
\text { et al. [23] }\end{array}$ & $\begin{array}{l}\text { P, methanol, } \\
\text { NG, EV }\end{array}$ & $\begin{array}{l}\text { Purchase price, fuel cost, } \\
\text { range, performance, fuel } \\
\text { availability and vehicle } \\
\text { emissions. }\end{array}$ & $\mathrm{CM}$ & $\begin{array}{l}\text { Consumers are willing to pay more } \\
\text { for vehicles with reduced emission } \\
\text { levels. }\end{array}$ & California (US) \\
\hline Segal [79] & $\mathrm{EV}$ & $\begin{array}{l}\text { Recharging/refuelling, range, } \\
\text { fuel attributes and cost of } \\
\text { the vehicle }\end{array}$ & $\mathrm{CM}$ & $\begin{array}{l}\text { Low market share of EVs as a result } \\
\text { of high purchase price and } \\
\text { inconvenience after sale. }\end{array}$ & California (US) \\
\hline $\begin{array}{l}\text { Sperling } \\
\text { et al. [81] }\end{array}$ & Methanol & $\begin{array}{l}\text { Higher octane, less pollution } \\
\text { and more power. }\end{array}$ & $\mathrm{CV}$ & $\begin{array}{l}\text { Higher WTP for clean fuels than for } \\
\text { more power, if the cost burden is } \\
\text { shared by all. }\end{array}$ & $\begin{array}{l}\text { New York and } \\
\text { California (US) }\end{array}$ \\
\hline $\begin{array}{l}\text { Brownstone } \\
\text { et al. [21] }\end{array}$ & AFV & $\begin{array}{l}\text { Purchase price, range, refuelling } \\
\text { cost and time, service station } \\
\text { refuelling time, service station } \\
\text { availability, acceleration time, } \\
\text { top speed, tailpipe emissions, } \\
\text { vehicle size, body type and } \\
\text { luggage space. }\end{array}$ & $\mathrm{CM}$ & $\begin{array}{l}\text { High income households are likely } \\
\text { to purchase high-priced vehicles, } \\
\text { 2-vehicle households with children } \\
\text { under } 21 \text { years expose a greater } \\
\text { WTP for emission reduction than } \\
\text { households without children and } \\
\text { vehicle range is a very important } \\
\text { concern when purchasing AFVs. }\end{array}$ & California (US) \\
\hline $\begin{array}{l}\text { Chéron and } \\
\text { Zins [27] }\end{array}$ & EV & $\begin{array}{l}\text { Range, maximum speed, } \\
\text { recharging time and cost } \\
\text { and delay in case of dead } \\
\text { battery. }\end{array}$ & $\mathrm{CM}$ & $\begin{array}{l}\text { No viable market for EVs unless } \\
\text { driving range and recharging time } \\
\text { are comparable to conventional } \\
\text { gasoline vehicles. These factors } \\
\text { can be hardly compensated by } \\
\text { greater cleanliness. }\end{array}$ & Montréal (Canada) \\
\hline Greene [42] & AFV & $\begin{array}{l}\text { Purchase price, fuel price, } \\
\text { fuel availability }\end{array}$ & $\mathrm{CV}$ & $\begin{array}{l}\text { The transition from initial market } \\
\text { development to a mature market } \\
\text { requires a minimum of } 10 \text { to } \\
20 \% \text { (of conventional gasoline } \\
\text { stations) AFV refuelling stations. }\end{array}$ & US \\
\hline $\begin{array}{l}\text { Ewing and } \\
\text { Sarigöllü [33] }\end{array}$ & $\begin{array}{l}\text { EV, fuel- } \\
\text { efficient, } \\
\text { conventional }\end{array}$ & $\begin{array}{l}\text { Purchase price, repair and } \\
\text { maintenance cost, range, } \\
\text { refuelling time, acceleration, } \\
\text { commuting time and cost, } \\
\text { polluting emissions. }\end{array}$ & $\mathrm{CM}$ & $\begin{array}{l}\text { Large market potential for cleaner } \\
\text { fuel-efficient vehicles and EVs if } \\
\text { they can compete with conventional } \\
\text { vehicles in price and performance. }\end{array}$ & Montreal (Canada) \\
\hline $\begin{array}{l}\text { Tompkins } \\
\text { et al. [87] }\end{array}$ & $\begin{array}{l}\text { NG/propane, } \\
\text { Alcohol, EV, } \\
\text { gasoline }\end{array}$ & $\begin{array}{l}\text { List of } 26 \text { attributes } \\
\text { manipulated by an } \\
\text { experimental design. }\end{array}$ & $\mathrm{CM}$ & $\begin{array}{l}\text { People are willing to pay a significant } \\
\text { amount to reduce emissions and } \\
\text { save on gas. }\end{array}$ & Continental US \\
\hline $\begin{array}{l}\text { Brownstone } \\
\text { et al. [22] }\end{array}$ & $\begin{array}{l}\text { P, EV, methanol, } \\
\text { CNG }\end{array}$ & $\begin{array}{l}\text { Purchase price, range, refuelling } \\
\text { cost and time, service station } \\
\text { refuelling time, service station } \\
\text { availability, acceleration time, } \\
\text { top speed, tailpipe emissions, } \\
\text { vehicle size, body type and } \\
\text { luggage space. }\end{array}$ & $\mathrm{CM}$ & $\begin{array}{l}\text { There exists a large heterogeneity in } \\
\text { consumer preferences for AFVs. } \\
\text { Respondents preferred CNG and } \\
\text { methanol to gasoline, only college- } \\
\text { educated respondents preferred EVs. }\end{array}$ & California (US) \\
\hline $\begin{array}{l}\text { Ewing and } \\
\text { Sarigöllü [34] }\end{array}$ & $\mathrm{AFVs}$ & $\begin{array}{l}\text { Purchase price, repair and } \\
\text { maintenance cost, cruising } \\
\text { range, refuelling time, } \\
\text { cceleration and polluting } \\
\text { emissions. }\end{array}$ & $\mathrm{CM}$ & $\begin{array}{l}\text { Although strong preferences were } \\
\text { found for AFVs, vehicle performance } \\
\text { characteristics are critical for their } \\
\text { acceptance. }\end{array}$ & Montreal (Canada) \\
\hline $\begin{array}{l}\text { Dagsvik } \\
\text { et al. [29] }\end{array}$ & $\begin{array}{l}\text { EV, LPG, } \\
\text { HEV, P }\end{array}$ & $\begin{array}{l}\text { Purchase price, driving range } \\
\text { between refuelling/recharging, } \\
\text { top speed and fuel consumption. }\end{array}$ & $\mathrm{CM}$ & $\begin{array}{l}\text { Low WTP for AFVs unless the } \\
\text { infrastructure for maintenance } \\
\text { and refuelling, purchase price } \\
\text { and driving range become fully } \\
\text { competitive compared to } \\
\text { conventional gasoline vehicles. }\end{array}$ & Norway (EU) \\
\hline
\end{tabular}


Table 5 (continued)

\begin{tabular}{|c|c|c|c|c|c|}
\hline Study & Scope & Attributes & Method & Findings & Location \\
\hline $\begin{array}{l}\text { Mourato } \\
\text { et al. [65] }\end{array}$ & $\mathrm{HFCV}$ & $\begin{array}{l}\text { Range, acceleration, top speed, } \\
\text { noise, emissions, electrical } \\
\text { equipment, internal dimensions, } \\
\text { boot space, safety, refuelling } \\
\text { costs and refuelling stations. }\end{array}$ & $\mathrm{CV}$ & $\begin{array}{l}\text { Despite environmental concern and } \\
\text { a supportive attitude towards green } \\
\text { cars, the WTP in the short term was } \\
\text { mainly determined by financial } \\
\text { considerations. Environmental } \\
\text { considerations and knowledge of } \\
\text { technology were found to affect } \\
\text { long-term purchasing decisions. }\end{array}$ & London (EU) \\
\hline Horne et al. [49] & $\begin{array}{l}\mathrm{NG}, \mathrm{HEV} \\
\mathrm{HFCV}, \mathrm{P}\end{array}$ & $\begin{array}{l}\text { Capital cost, operating cost, fuel } \\
\text { availability, express lane access, } \\
\text { emissions data and power. }\end{array}$ & $\mathrm{CM}$ & $\begin{array}{l}\text { High market share prediction for } \\
\text { HEVs and HFCVs, if all attributes } \\
\text { are equal. }\end{array}$ & Canada \\
\hline $\begin{array}{l}\text { Lundquist } \\
\text { Noblet et } \\
\text { al. }[60]\end{array}$ & $\begin{array}{l}\text { Eco-labeled } \\
\text { cars }\end{array}$ & $\begin{array}{l}\text { Income, annualised price, annual } \\
\text { driving cost, pollution criteria, } \\
\text { faith in orders, perceived } \\
\text { consumer effectiveness, } \\
\text { perceived compromise needed } \\
\text { when buying greener vehicles, } \\
\text { knowledge on link between air } \\
\text { quality degradation and vehicle } \\
\text { emissions and air quality concern. }\end{array}$ & $\mathrm{CM}$ & $\begin{array}{l}\text { Environmental attributes of an eco- } \\
\text { labeled car are significant in the } \\
\text { purchase decision. Eco-information } \\
\text { is considered in the vehicle purchase } \\
\text { decision, but not at class-level } \\
\text { decision. Individuals with different } \\
\text { perceptions and norms react } \\
\text { differently to eco-information. }\end{array}$ & Maine (Canada) \\
\hline $\begin{array}{l}\text { Potoglou and } \\
\text { Kanaroglou } \\
\text { [72] }\end{array}$ & $\mathrm{HEV}, \mathrm{AFV}, \mathrm{P}$ & $\begin{array}{l}\text { Purchase price, annual fuel, } \\
\text { maintenance costs, fuel } \\
\text { availability, economic } \\
\text { incentives, acceleration } \\
\text { and pollution level. }\end{array}$ & $\mathrm{CM}$ & $\begin{array}{l}\text { Individuals consider price and } \\
\text { performance characteristics as } \\
\text { important. They are attracted by } \\
\text { reduced emission levels, but limited } \\
\text { fuel availability is a major concern. }\end{array}$ & $\begin{array}{l}\text { Hamilton } \\
\text { (Canada) }\end{array}$ \\
\hline Ahn et al. [3] & $\begin{array}{l}\text { P, D, CNG, } \\
\text { LPG, HEV }\end{array}$ & $\begin{array}{l}\text { Fuel type, body type, maintenance } \\
\text { cost, engine displacement, fuel } \\
\text { efficiency and fuel price. }\end{array}$ & $\mathrm{CM}$ & $\begin{array}{l}\text { AFVs can only gain market share if } \\
\text { their purchase price is equal to that } \\
\text { of a conventional vehicle. A HEV } \\
\text { is valued as the most attractive } \\
\text { alternative because of its low fuel } \\
\text { costs, although this type of car has } \\
\text { a disadvantageous purchase price. }\end{array}$ & Seoul (Asia) \\
\hline Mau et al. [62] & $\mathrm{HEV}, \mathrm{HFCV}, \mathrm{P}$ & $\begin{array}{l}\text { Purchase price, fuel cost, subsidy, } \\
\text { warranty coverage, cruising } \\
\text { range and refuelling convenience. }\end{array}$ & $\mathrm{CM}$ & $\begin{array}{l}\text { The importance that consumers place } \\
\text { on certain attributes changes over } \\
\text { time as a new technology gains market } \\
\text { share (i.e., neighbour effect). HEVs } \\
\text { are found more acceptable than HFCV } \\
\text { as the former provides the same service } \\
\text { as a conventional technology whereas } \\
\text { the latter possesses attributes that are } \\
\text { unfamiliar to consumers. }\end{array}$ & Canada (US) \\
\hline $\begin{array}{l}\text { Solomon and } \\
\text { Johnson [80] }\end{array}$ & Ethanol & $\begin{array}{l}\text { WTP for ethanol made from } \\
\text { farming residues, forestry } \\
\text { residues, paper mill wastes } \\
\text { and municipal solid wastes. }\end{array}$ & $\mathrm{CV}$ & $\begin{array}{l}\text { Females, political liberals, higher } \\
\text { income-households and environmental } \\
\text { concern positively affect the WTP } \\
\text { for ethanol. No statistical differences } \\
\text { in WTP for the different feedstocks } \\
\text { were found. }\end{array}$ & Minnesota (US) \\
\hline Axsen et al. [10] & $\begin{array}{l}\mathrm{HEV}, \\
\text { conventional }\end{array}$ & $\begin{array}{l}\text { Capital cost, subsidy, performance, } \\
\text { fuel efficiency and fuel price. }\end{array}$ & $\mathrm{CM}$ & $\begin{array}{l}\text { WTP for HEVs is higher with a } \\
\text { higher HEV penetration. }\end{array}$ & $\begin{array}{l}\text { Canada and } \\
\text { California (US) }\end{array}$ \\
\hline $\begin{array}{l}\text { Caulfield } \\
\text { et al. [26] }\end{array}$ & $\begin{array}{l}\mathrm{HEV}, \mathrm{AFV} \\
\text { conventional }\end{array}$ & $\begin{array}{l}\text { Fuel costs, vehicle registration tax, } \\
\mathrm{CO}_{2} \text { emissions. }\end{array}$ & $\mathrm{CM}$ & $\begin{array}{l}\text { HEVs are found to be better for the } \\
\text { environment and cheaper to run, } \\
\text { but more expensive to buy than } \\
\text { conventional vehicles. }\end{array}$ & Ireland (EU) \\
\hline $\begin{array}{l}\text { Eggers and } \\
\text { Eggers [31] }\end{array}$ & $\begin{array}{l}\mathrm{EV}, \mathrm{HEV} \\
\text { conventional }\end{array}$ & $\begin{array}{l}\text { Drive train technology, range-per- } \\
\text { battery charge and price as } \\
\text { compared to conventional cars. }\end{array}$ & $\mathrm{CM}$ & $\begin{array}{l}\text { Critical adoption factors for EVs } \\
\text { are purchase price, range, timing } \\
\text { of market entry, or environmental } \\
\text { evolution (e.g., increasing penetration, } \\
\text { rising gas prices, or increasing number } \\
\text { of electric charging stations). }\end{array}$ & Germany (EU) \\
\hline $\begin{array}{l}\text { Jensen } \\
\text { et al. [51] }\end{array}$ & Ethanol & $\begin{array}{l}\text { Fuel price, feedstock (corn grain, } \\
\text { switchgrass and wood wastes), } \\
\text { fuel import, GHG emission } \\
\text { reductions and fuel availability. }\end{array}$ & $\mathrm{CV}$ & $\begin{array}{l}\text { Females, younger respondents and higher } \\
\text { concern about independence from foreign } \\
\text { energy sources positively affected the } \\
\text { WTP for the different feedstocks. GHG } \\
\text { emission reduction also positively } \\
\text { influenced the WTP for E85. }\end{array}$ & US \\
\hline
\end{tabular}


Table 5 (continued)

\begin{tabular}{|c|c|c|c|c|c|}
\hline Study & Scope & Attributes & Method & Findings & Location \\
\hline $\begin{array}{l}\text { Erdem } \\
\text { et al. [32] }\end{array}$ & HEV & WTP for HEV & $\mathrm{CV}$ & $\begin{array}{l}\text { Income, educational level, } \\
\text { environmental concern, risk attitudes, } \\
\text { gender and perception of alternative } \\
\text { energy sources have a positive impact } \\
\text { on the WTP for a HEV. }\end{array}$ & Turkey (EU) \\
\hline $\begin{array}{l}\text { Petrolia } \\
\text { et al. [68] }\end{array}$ & Ethanol and $\mathrm{P}$ & WTP for E10 and E85 & $\mathrm{CV}$ & $\begin{array}{l}\text { WTP for E10 is lower for older } \\
\text { respondents, for those who prefer } \\
\text { public transit options and those who } \\
\text { prefer non-ethanol-fuelled vehicle } \\
\text { alternatives, but higher for those } \\
\text { with higher education levels. }\end{array}$ & US \\
\hline
\end{tabular}

The reviewed studies, summarised in Table 6, mostly relied on semiotic theory to unveil the symbolic meanings associated to AFVs in California (US). They all agree on the fact that households are not purchasing AFVs for their functional or economic benefits, but to gain access to symbols that are used to define and express who they are.

Symbolism is found to be particularly strong in vehicles that use new types of technologies. They were important to early buyers of EVs in Norway [36] and HEVs in the US $[45,46]$. Heffner et al. [45] used ethnographic interviews with 25 early HEV buyers to explore how widely recognised social meanings (denotations) are connected to more personal meanings (connotations) and how they affect vehicle purchase. They revealed that households buy HEVs for the meanings they symbolise (such as "environmental preservation", "financial responsibility", "independence from oil producers", "embracing new technology" and "opposition to war") as well as the connotations linked to these ideas that are relevant to self-identity (such as "concern about others", "intelligence", "independence", "uniqueness", "ethics", etc.). While denotations are generally socially-shared, connotations vary from person to person. For example, two households may view their HEV as a symbol for "preserving the environment", but one household may emphasise the "ethics" connotation, whereas for another household their "concern about others" is an important value to communicate to society $[45,88]$.

Heffner et al. [46] recommend that, just as early buyers of HEVs looked for meanings that were unavailable in other types of vehicles; early buyers of HFCVs will also look for new symbolic meanings in their vehicles that are not offered

Table 6 Reviewed other studies

\begin{tabular}{|c|c|c|c|c|}
\hline Study & Scope & Setting & Findings & Location \\
\hline Gjoen and Hard [36] & $\mathrm{EV}$ & Interviews. & $\begin{array}{l}\text { EVs are associated with symbolic meanings } \\
\text { such as a contribution to a cleaner environmental } \\
\text { consciousness. }\end{array}$ & Norway (EU) \\
\hline Turrentine and Kurani [88] & - & $\begin{array}{l}\text { Semi-structured interviews } \\
\text { with } 57 \text { households. }\end{array}$ & $\begin{array}{l}\text { High fuel economy may be valued more for its } \\
\text { symbolism (e.g., resource conservation) than } \\
\text { for its marginal financial value }\end{array}$ & California (US) \\
\hline \multirow[t]{5}{*}{ Heffner et al. [45] } & \multirow[t]{5}{*}{ HEV } & $\begin{array}{l}\text { Semi-structured ethnographic } \\
\text { interviews with } 25 \mathrm{HEV} \\
\text { owners including sections on: } \\
\text { - household vehicle history }\end{array}$ & $\begin{array}{l}\text { The purchase of an HEV is influenced by } 5 \\
\text { denotations, each associated with several } \\
\text { connotations: } \\
\text { - preserving the environment (ethical, concerned } \\
\text { about others) }\end{array}$ & \multirow[t]{5}{*}{ California (US) } \\
\hline & & - purchase narrative & - opposed to war (ethics) & \\
\hline & & - symbolic meaning analysis & - manage personal finances (maturity, intelligence) & \\
\hline & & - HEV benefits and disbenefits & - reduce oil support (personal, national independence) & \\
\hline & & - vehicle preference exercise & - embrace new technology (individuality, unique) & \\
\hline Heffner et al. [46] & $\mathrm{HFCV}$ & See Heffner et al. [45]. & $\begin{array}{l}\text { Just as in case of HEVs (see [45]), HFCVs should } \\
\text { be differentiated based on these existing meanings } \\
\text { and offer new symbolic meanings such as the idea } \\
\text { of "extended personal territory", as they have the } \\
\text { potential to provide electricity, even when the } \\
\text { vehicle is not in use. }\end{array}$ & California (US) \\
\hline
\end{tabular}


by competing alternatives. In this respect, HFCVs should improve on existing symbolic meanings (e.g., by providing potential buyers a more authentic access to the ideas of environmental preservation or advanced technology). In addition, they should offer entirely new symbolic meanings as well such as "home refuelling", which can refer to aspects of independency. Another possibility is to explore the idea of "extended personal territory", as HFCVs have the potential to produce clean electrical power for purposes other than propulsion. As new meanings will continue to emerge, understanding the meanings, as well as their construction and communication is essential to promote the AFV market.

\section{Conclusions and recommendations}

4.1 Conceptual framework and research methodologies of reviewed studies

This paper reviewed 53 publications according to the applied conceptual framework and research methodology. Overall, the amount of articles dealing with consumer preferences and attitudes towards AFVs has grown considerably over time. Research from the 80s and 90s was mainly carried out in California and applied preference valuation techniques and experimental designs to elicit consumer preferences for EVs. Recent studies, mainly executed in Europe and (North) America, give more emphasis to biofuels, hydrogen, (P)HEVs and HFCVs and also apply attitudinal surveys and (symbolic) qualitative surveys as reaction to the traditional rational-actor approaches. Early studies from the US often focused on EVs, which possess vehicle attributes that are unfamiliar to consumers. As a result, performance characteristics often came out as the critical acceptance factors. In recent studies from the EU, focusing on evolutionary technologies such as HEV or hydrogen, price characteristics play a more important role as the consumers are much more familiar with the performance attributes.

The predominant method used in measuring the consumer preferences for AFVs is CM, which principal aim is to unveil the different critical factors for the adoption of AFVs. A common criticism of $\mathrm{CM}$ is that they might not capture the complexity of a consumer purchase decision as it (1) only presents a small (pre-defined) selection of vehicle attributes in order to reduce the cognitive burden of the respondent and to allow proper measurement-leaving people no possibility to frame the perceptions by themselves and (2) assumes that respondents have preferences for attributes (such as driving range, home recharging) that are unfamiliar and unknown to them. A common criticism of SP surveys which also applies to (quantitative) attitudinal surveys is that the potential demand for green and progressive technologies might be overstated as a result of social desirable answers. In this respect, qualitative surveys (such as in symbolic studies and attitudinal surveys) and experimental based approaches (trials, travel diaries, etc.) increase familiarity and experience with the alternative technologies and offer more opportunities to deal with the sociocultural contexts in which values, beliefs, perceptions and attitudes are rooted. On the other hand, these studies often contain small samples which are unlikely to be representative for wider populations.

The technological focus of experimental studies and symbolic studies is merely on EVs, PHEVs and HFCVs. These technologies not only face driving range and infrastructure challenges, but also possess new vehicle qualities such as silent driving, home recharging, etc. Experimental and symbolic studies mainly envision the early buyers segment and examine whether these new vehicle characteristics can offset the limitations (experimental studies) or even symbolise new meanings that can be communicated to society (symbolic studies). Attitudinal studies are rather performed to uncover the consumer attitudes for biofuels and hydrogen whereas consumer preference studies often deal with a variety of technologies. A potential gap in most of the reviewed studies is that they focus solely on the preferences for one technology [75]. Ideally, conventionally fuelled vehicles and other competing clean vehicle technologies should be incorporated in the study design to provide a better reflection of the range of alternatives that are available in the market and to improve realism.

\subsection{Key results of reviewed studies}

Overall, the key finding from the reviewed studies is that there exists a strong environmental concern, and positive attitudes towards AFVs, but that the environmental benefits are of little importance in the car purchase decision.

Attitudinal studies refer to this phenomenon as the attitude-action gap, as positive environmental attitudes do not translate into ecological behaviour. The revised literature revealed that attitudes of people are not only determined by environmental considerations, but also by a complex tradeoff involving the perceived costs and benefits of the various alternatives. Moreover, limited knowledge levels currently prevent to build up awareness of AFVs, which is the key for their adoption.

Most experimental studies shared the opinion that a shortterm exposure to AFVs improves the respondents' overall impressions, especially with respect to their environmental benefits. But once experience with AFVs is gained, environmental benefits become of minor importance as other vehicle features (e.g., driving range) will enter the decision set. Nevertheless, some studies stipulate that acquired experience with AFVs attract so-called "hybrid households", because of their new qualities (e.g., quite ride, low running costs, home recharging) which can more than offset the disutility of a reduced range. Again, these studies also recognise that 
environmental concern is not an important attribute in the car purchase decision, even for early AFV buyers.

The reviewed preference valuation studies unveiled that environmental benefits are of minor importance for the adoption of AFVs, which is principally driven by price characteristics, performance and convenience attributes. Additionally, the revised CV studies highlighted that the WTP for AFVs is positively influenced by socio-economic (e.g., income) and psychological characteristics (e.g., environmental concern), but that ultimately the WTP is still driven by expectations of personal financial savings. Recent studies also reveal that the degree of market penetration of AFVs might exert a strong influence on consumer preferences (i.e., neighbour effect), given equal monetary costs. However, these dynamics seem to depend on the type of technology such that preferences will be stronger for evolutionary technologies (e.g., HEV) than for disruptive technologies (e.g., HFCVs, EVs) as the latter possess vehicle attributes that are unfamiliar to consumers and require technical infrastructure.

Lastly, a different approach is the acknowledgment of symbolism as a central aspect of vehicle ownership. All revised studies agree on the fact that households do not purchase AFVs based on rational factors, such as functional or economic benefits, but to gain access to a variety of denotations and associated connotations behind it. In this respect, people might purchase an AFV as it symbolises "environmental preservation" and refers to a range of connotations such as "ethics", "intelligence", "awareness" or "concern about others".

\subsection{Policy recommendations}

The adoption of AFVs is likely to be limited without significant governmental incentives and regulations.

Given the low awareness of AFVs found in the reviewed attitudinal studies, information provision is a prerequisite for changing environmental behaviour. It should be diversified according to the heterogeneous target audience (e.g., along their interests, knowledge, attitudes, socio-demographics, etc.) and should especially focus on the opportunities and possible solutions such as the range of actions that can be taken within car purchase to reduce energy problems. As AFVs are often associated with reduced performance and comfort, information about their performance potential might even attract people that are uninterested in environmental issues.

Besides educational campaigns to raise awareness about the features of AFVs, experimental studies and preference valuation techniques also highlight the need for pricing measures (e.g., differentiation of taxation based on fuel consumption or $\mathrm{CO}_{2}$ emissions, subsidies, etc.), supplysided measures (e.g., recharging, refuelling network) and large-scale demonstrations to ensure the financial attractiveness, availability and reliability of AFVs.
According to the symbolic studies, the market success of AFVs will depend on the existing and new symbolic meanings that are attached to these vehicles. In case of EVs, PHEVs and HFCVs, the challenge is thus to exploit new symbolic meanings that were not previously available in other vehicle types. However, if one wants to offer potential buyers stronger, more authentic access to these symbolic meanings such as "environmental preservation", "oil independence" or "financial acumen", a broad consensus about their environmentally friendly aspects or financial attractiveness should exist. Any confusion about these aspects (e.g., about the sustainability of the fuel on a well-to-wheel basis) could strip these potential symbolic meanings from AFVs. In this respect, common information tools that provide factual information on the potential environmental and financial benefits of AFVs are required in order to distinguish them from conventionally fuelled vehicles.

Acknowledgments The authors would like to acknowledge the financial support by the Belgian Science Policy (BELSPO).

Open Access This article is distributed under the terms of the Creative Commons Attribution License which permits any use, distribution, and reproduction in any medium, provided the original author(s) and the source are credited.

\section{References}

1. Abley J (2000) Stated Preference techniques and consumer decision making: new challenges to old assumptions. Cranfield University, pp 40

2. Achterberg P, Houtman D, van Bohemen S, Manevska K (2010) Unknowing but supportive? Predispositions, knowledge, and support for hydrogen technology in the Netherlands. Int J Hydrog Energy 35:6075-6083

3. Ahn J, Jeong G, Kim Y (2008) A forecast of household ownership and use of alternative fuel vehicles: a multiple discrete-continuous choice approach. Energy Econ 30:2091-2104

4. Ajzen I (1985) From Intentions to Actions: a theory of planned behavior. In: Kuhl J, Beckman J (eds) Action-control: from cognition to behavior. Springer, Heidelberg, pp 11-39

5. Ajzen I (1991) The theory of planned behavior. Organ Behav Hum Decis Process 50:179-211

6. Anderson NH (1981) Foundations of information integration theory. Academic, NJ

7. Anderson S, Stradling SG (2004) Attitudes to car use and modal shift in Scotland. Report of National Centre for Social Research, Scotland: Scottish Executive Social Research. Available at: http:// www.scotland.gov.uk/Publications/2004/03/19062/34290

8. Armitage CJ, Conner M (2001) Efficacy of the theory of planned behaviour: a meta-analytic review. Br J Soc Psychol 40:471-499

9. Axsen J, Kurani KS (2010) Anticipating plug-in hybrid vehicle energy impacts in California: constructing consumer-informed recharge profiles. Transp Res D 15:212-219

10. Axsen J, Mountain DC, Jaccard M (2009) Combining stated and revealed choice research to stimulate the neighbor effect: the case of hybrid-electric vehicles. Resour Energy Econ 31:221-238

11. Axsen J, Kurani KS, Burke A (2010) Are batteries ready for plugin hybrid buyers? Transp Policy 17:173-182 
12. Bateman IJ, Carson RT, Day B, Hanemann M, Hanley N, Hett T, Jones-Lee M, Loomes G, Mourato S, Ozdemiroglu E, Pearce DW, Sugden R, Swanson J (2002) Economic valuation with stated preference techniques: a manual. Edward Elgar, Ltd., Cheltenham, p 458

13. Beggs SD, Cardell NS (1980) Choice of smallest car by multivehicle households and the demand for electric vehicles. Transp Res A 14(A):389-404

14. Beggs SD, Cardell NS, Hausman J (1981) Assessing the potential demand for electric cars. J Econom 17:1-19

15. Bettman J, Luce M, Payne J (1998) Constructive consumer choice processes. J Consum Res 25(3):187-217

16. Bhatt CR (2005) A multiple discrete-continuous extreme value (MDCEV) model: role of utility function parameters, identification considerations, and model extensions. Transp Res B 42(3):274-303

17. Bhatt CR, Sen S, Eluru N (2009) The impact of demographics, built environment attributes, vehicle characteristics, and gasoline prices on household vehicle holdings and use. Transp Res B 43:1-18

18. Blamey RK, Bennett JW, Louviere JJ, Morrison MD, Rolfe J (2000) A test of policy labels in environmental choice modelling studies. Ecol Econ 32:269-286

19. Bontekoning YM, Macharis C, Trip JJ (2002) Is a new applied transportation research field emerging? A review of intermodal rail-truck freight transport literature. Transp Res A 38(1):1-34

20. Brownstone D, Small K (2005) Valuing time and reliability: assessing the evidence from road pricing demonstrations. Transp Res A 39(3):279-293

21. Brownstone D, Bunch DS, Golob TF, Ren W (1996) A transactions choice model for forecasting demand for alternative-fuel vehicles. Res Transp Econ 4:87-129

22. Brownstone D, Bunch DS, Train K (2000) Joint mixed logit models of stated and revealed preferences for alternative fuel vehicles. Transp Res B 34(5):315-338

23. Bunch DS, Bradley M, Golob TF, Kitamura R, Occhiuzzo GP (1993) Demand for alternative-fuel vehicles in California: a discrete-choice stated preference pilot project. Transp Res A 27:237-253

24. Calfee JE (1985) Estimating the demand for electric automobiles using disaggregated probabilistic choice analysis. Transp Res B 19(4):287-301

25. Carson RT (2000) Contingent valuation: a user's guide. Environ Sci Technol 34:1413-1418

26. Caulfield B, Farrell S, McMahon B (2010) Examining individuals preferences for hybrid electric and alternatively fuelled vehicles. Transp Policy 17:381-387

27. Chéron E, Zins M (1997) Electric vehicle purchasing intentions: the concern over battery charge duration and risk of failure. Transp Res A 31:235-243

28. Cooper HM (1989) Integrating research: a guide for literature reviews. Applied social research methods series 2. Sage Publications, Newbury Park

29. Dagsvik JK, Wennemo T, Wetterwald DG, Aaberge R (2002) Potential demand for alternative fuel vehicle. Transp Res B 36:361-384

30. Eagly AH, Chaiken S (1993) The psychology of attitudes. Harcourt Brace Jovanovich College Publications

31. Eggers F, Eggers F (2010) Where have all the flowers gone? Forecasting green trends in the automobile industry with a choice-based conjoint adoption model. Technol Forecast Soc Chang. doi:10.1016/j.techfore.2010.06.014

32. Erdem C, Sentürk I, Simsek T (2010) Identifying the factors affecting the willingness to pay for fuel-efficient vehicles in Turkey: a case of hybrids. Energy Policy 38:3038-3043

33. Ewing GO, Sarigöllü E (1998) Car fuel-type choice under travel demand management and economic incentives. Transp Res D 3(6):429-444

34. Ewing GO, Sarigöllü E (2000) Assessing consumer preferences for clean-fuel vehicles: a discrete choice experiment. J Public Policy Mark 19(1):106-118
35. Flamm B (2009) The impacts of environmental knowledge and attitudes on vehicle ownership and use. Transp Res D. doi:10.1016/j.trd.2009.02.003

36. Gjoen H, Hard M (2002) Cultural politics in action: developing user scripts in relation to the electric vehicle. Sci Technol Hum Values 27(2):262-281

37. Glazer A, Klein DB, Lave C (1995) Clean on paper, dirty on the road: troubles with California's smog check. The University of California Transportation Center. J Transp Economics Policy, pp 11

38. Golob TF, Gould J (1998) Projecting use of electric vehicles from household vehicle trials. Transp Res B 32(7):441-454

39. Gould J, Golob TF (1998) Clean air forever? A longitudinal analysis of opinions about air pollution and electric vehicles. Transp Res D 3(3):157-169

40. Gredler M (1992) Designing and evaluating games and simulations: a process approach. Kogan Page, London

41. Green PE, Srinivasan V (1990) Conjoint analysis in Marketing: new development with implications for research and practice. $\mathrm{J}$ Mark 54:3-19

42. Greene DL (1996) Survey evidence on the importance of fuel availability to the choice of alternative fuels and vehicles. Energy Stud Rev 8(3):215-231

43. Hanly N, MacMillan D, Wright RE, Bullock C, Simpson I, Parsisson D, Crabtree B (1998) Contingent valuation versus choice experiments: estimating the benefits of environmentally sensitive areas in Scotland. J Agr Econ 49(1):1-15

44. Hanly N, Mourato S, Wright RE (2001) Choice modelling approaches: a superior alternative for environmental valuation? J Econ Surv 15(3):436-462

45. Heffner RR, Kurani S, Turrentine TS (2007) Symbolism in California's early market for hybrid electric vehicles. Transp Res D 12:396-413

46. Heffner RR, Kurani KS, Turrentine TS (2007) Symbolism and the adoption of fuel-cell vehicles. World Electr Vehicle Assoc J 1:24-31

47. Hensher D (2010) Hypothetical bias, choice experiments and willingness to pay. Transp Res B 44:735-752

48. Hickman R, Ashiru O, Banister D (2010) Transport and climate change: simulating the options for carbon reduction in London. Transp Policy 17:110-125

49. Horne M, Jaccard M, Tiedemann K (2005) Improving behavioral realism in hybrid energy-economy models using discrete choice studies of personal transportation decisions. Energy Econ 27:59-77

50. Hoyos D (2010) The state of the art of environmental valuation with discrete choice experiments. Ecol Econ 69:1595-1603

51. Jensen KL, Clark CD, English BC, Menard RJ, Skahan DK, Marra AC (2010) Willingness to pay for E85 from corn, switchgrass, and wood residues. Energy Econ 32:1253-1262

52. Johansson-Stenman O, Martinsson P (2006) Honestly, why are you driving a BMW? J Econ Behav Organ 60:129-146

53. Kahn ME (2007) Do greens drive hummers or hybrids? Environmental ideology as a determinant of consumer choice. J Environ Econ Manag 54:129-145

54. Kurani K, Turrentine T, Sperling D (1994) Demand for electric vehicles in hybrid households: an exploratory analysis. Transp Policy 1(4):244-256

55. Kurani K, Turrentine T, Sperling S (1996) Testing electric vehicle demand in 'hybrid households' using a reflexive survey. Transp Res D 1(2):131-150

56. Lane B, Potter S (2007) The adoption of cleaner vehicles in the UK: exploring the consumer attitude-action gap. J Clean Prod 15:1085-1092

57. Lois D, López-Sáez M (2009) The relationship between instrumental, symbolic and affective factors as predictors of car use: a structural equation modeling approach. Transp Res 1(43):790-799

58. Louviere J, Hensher DA (1982) On the design and analysis of simulated choice or allocation experiments in travel choice modelling. Transp Res Rec 890:11-17 
59. Louviere J, Woodworth G (1983) Design and analysis of simulated consumer choice or allocation experiments: an approach based on aggregate data. J Mark Res 20:350-367

60. Lundquist Noblet C, Teisl MF, Rubin J (2006) Factors affecting consumer assessment of eco-labeled vehicles. Transp Res D $11: 422-431$

61. Martin E, Shaheen SA, Lipman TE, Lidicker JR (2009) Behavioral response to hydrogen fuel cell vehicles and refuelling: results of California drive clinics. Int J Hydrogen Energ 34(20):8670-8680

62. Mau P, Eyzaguirre J, Jaccard M, Collins-Dodd C, Tiedemann K (2008) The "neighbor effect": simulating dynamics in consumer preferences for new vehicle technologies. Ecol Econ 68:504-516

63. Mitchell RC, Carson RT (1989) Using surveys to value public goods: the contingent valuation method. Resources for the future, Washington, DC

64. Mogas J, Riera P, Bennett J (2006) A comparison of contingent valuation and choice modeling with second-order interactions. $\mathrm{J}$ For Econ 12:5-30

65. Mourato S, Saynor B, Hart D (2004) Greening London's black cabs: a study of driver's preferences for fuel cell taxis. Energy Policy 32:685-695

66. O'Garra T, Mourato S, Pearson P (2005) Analysing awareness and acceptability of hydrogen vehicles: a london case study. Int J Hydrog Energy 30:649-659

67. Peters A, Gutscher H, Scholz RW (2011) Psychological determinants of fuel consumption of purchased new cars. Transp Res F. doi:10.1016/j.trf.2011.01.003

68. Petrolia DR, Bhattacharjee S, Hudson D, Herndon CW (2010) Do Americans want ethanol? A comparative contingent-valuation study of willingness to pay for E10 and E85. Energy Econ 32:121-128

69. Popp M, Van de Velde L, Vickery G, Van Huylenbroeck G, Verbeke W, Dixon B (2009) Determinants of consumer interest in fuel economy: lessons for strengthening the conservation argument. Biomass Bioenergy 33:768-778

70. Potoglou D, Kanaroglou PS (2006) An internet based stated choices household survey for alternative fuelled vehicles. Centre for Spatial Analysis, Canada, p 21

71. Potoglou D, Kanaroglou PS (2006) Household demand and willingness to pay for alternative fuelled vehicles. Centre for Spatial Analysis, Canada, p 30

72. Potoglou D, Kanaroglou PS (2007) Household demand and willingness to pay for clean vehicles. Transp Res D Transp Env 12(4):264-274

73. Purcher J, Renne JL (2003) Socioeconomics of urban travel: evidence from the 2001 NHTS. Transp Q 57(3):49-77

74. Ricci M, Bellaby P, Flynn R (2008) What do we know about public perceptions and acceptance of hydrogen? A critical review and new case study evidence. Int J Hydrog Energy 33:5868-5880

75. Roche MY, Mourato S, Fischedick M, Pietzner K, Veibahn P (2010) Public attitudes towards and demand for hydrogen and fuel cell vehicles: a review of the evidence and methodological implications. Energy Policy 38:5301-5310
76. Schulte I, Hart D, van der Vorst R (2004) Issues affecting the acceptance of hydrogen fuel. Int J Hydrog Energy 29:677-685

77. Schwartz SH (1977) Normative influence on altruism. In: Berkowitz L (ed) Advances in experimental psychology. Academic, New York

78. Schwartz SH, Howard JA (1981) A normative decision-making model of altruism. In: Rushton PJ, Sorrentino RM (eds) Altruism and helping behaviour: social, personality, and developmental perspectives. Erlbaum, Hillsdale

79. Segal R (1995) Forecasting the market for electric vehicles in California using conjoint analysis. Energy J 16:89-111

80. Solomon BD, Johnson NH (2009) Valuing climate change protection through willingness to pay for biomass ethanol. Ecol Econ 68:2137-2144

81. Sperling D, Setiawan W, Hunderford D (1995) The target market for methanol fuel. Transp Res A 29(1):33-45

82. Steg L, Vlek C, Slotegraaf G (2001) Instrumental-reasoned and symbolic-affective motives for using a motor car. Transp Res F 4:151-169

83. Stern PC, Dietz T, Kalof L (1993) Value orientations, gender, and environmental concern. Environ Behav 25(3):322-348

84. Stern PC, Dietz T, Abel T, Guagnano GA, Kalof L (1999) A valuebelief-norm theory of support for social movements: the case of environmentalism. Res Hum Ecol 6(2):81-97

85. Tedeshi RG, Cann A, Siegfried WD (1982) Participation in voluntary auto emissions inspection. J Soc Psychol 117:309-310

86. Thesen G, Langhelle O (2008) Awareness, acceptability and attitudes towards hydrogen vehicles and filling stations: a greater Stavanger case study and comparisons with London. Int J Hydrog Energy 33:5859-5867

87. Tompkins M, Bunch D, Santini D, Bradley M, Vyas A, Poyer D (1998) Determinants of alternative vehicle choice in the continental United States. J Transp Res Board 1641:130-138

88. Turrentine TS, Kurani KS (2007) Car buyers and fuel economy? Energy Policy 35:1213-1223

89. Ulmer JD, Huhnke RL, Bellmer DD, Cartmell DD (2004) Acceptance of ethanol-blended gasoline in Oklahoma. Biomass Bioenergy 27:437-444

90. Urban G, Weinberg B, Hauser J (1994) Premarket forecasting of really new products. J Mark 60:47-60

91. Van de Velde L, Verbeke W, Popp M, Van Huylenbroeck G (2010) The importance of message framing for providing Information about sustainability and environmental aspects of energy. Energy Policy 38:5541-5549

92. Van Mierlo J, Macharis C (2005) Goederen - en Personenvervoer: vooruitzichten en breekpunten. Garant, Antwerpen, Apeldoorn

93. Van Mierlo J, Timmermans JM, Matheys J, Van den Bossche P (2006) Milieuvriendelijke voertuigen. VWEC, Mobiliteit en (groot) stedenbeleid, pp 447-490

94. Van Rijnsoever F, Farla J, Dijst MJ (2009) Consumer car preferences and Information search channels. Transp Res D 14:334-342

95. Venkatachalam L (2004) The contingent valuation method: a review. Environ Impact Assess Rev 24:89-124 